\begin{tabular}{rr} 
çağdaş & Yaratıcı Drama Dergisi 2015, 10(1), 15-30 \\
drama & www.yader.org \\
\hline
\end{tabular}

\title{
İlkokul 2. Sınıf Hayat Bilgisi Dersinin Drama Yöntemi ile Öğretimine İlişkin Bir Uygulama Önerisi
}

\author{
Hadiye Küçükkaragöz $\mathbf{z}^{1}$
}

Derya Av Hartuç²

\begin{tabular}{|c|c|}
\hline Makale Bilgisi & $\ddot{\mathbf{O} z}$ \\
\hline DOI: $10.21612 /$ yader.2015.002 & Hayat Bilgisi öğretim programının yapılandırmacı yaklaşıma göre düzenlenmesiyle \\
\hline $\begin{array}{l}\text { Anahtar Sözcükler } \\
\text { Hayat bilgisi } \\
\text { Yapılandırmacı yaklaşım } \\
\text { Drama yöntemi }\end{array}$ & $\begin{array}{l}\text { birlikte öğrencilerin öğrenme sürecine yaparak yaşayarak katılımını destekleyen } \\
\text { yöntemlerden biri de drama yöntemi olduğu söylenebilir. Bu araştırmada } \\
\text { ilkokul öğretmenlerinin 2. sınıf Hayat Bilgisi ders konularını drama yöntem ve } \\
\text { tekniklerini kullanarak daha etkili bir şekilde işleyebilmeleri için bir uygulama } \\
\text { önerisi ortaya konulmuştur. Kullanılan yöntem ve tekniklerin, çocukların eğitim } \\
\text { ve ögretim hayatındaki ve Hayat Bilgisi ders programının içeriğindeki yeri ve } \\
\text { önemi betimlenmiştir. Araştırmada alan yazın tarama ile drama ile ilgili yazılmış } \\
\text { tez, makale, kitap vb. yazılı basılı kaynaklar taranarak yarı yapılandırılmış form } \\
\text { ile toplanan öğretmen görüşleri ışığında 2014-2015 eğitim öğretim yılı için } \\
\text { hazırlanan Milli Eğitim Bakanlığ onaylı 2. Sınıf Hayat Bilgisi ders kılavuzundaki } \\
\text { "Okul Heyecanım”, "Benim Eşsiz Yuvam"ve "Dün, Bugün, Yarın” temalarındaki } \\
\text { konular ele alınarak dramadaki tekniklerin uygulanması ile ilgili ders planları } \\
\text { hazırlanmıştır. Çalışma sonucunda hazırlanan ders planları alınan öğretmenlerin } \\
\text { görüşlerine de dayanarak sonuçlar alan yazın ışığında tartışılmıştır. }\end{array}$ \\
\hline
\end{tabular}

\section{An Application Proposal for The Use of Drama Method in Teaching $2^{\text {nd }}$ Grade Life Science Courses}

\begin{tabular}{|c|c|}
\hline Article Info & Abstract \\
\hline DOI: $10.21612 /$ yader.2015.002 & Along with the arrangement of Life Sciences teaching program in accordance \\
\hline $\begin{array}{l}\text { Keywords } \\
\text { Life sciences } \\
\text { Constructivist approach } \\
\text { Drama method }\end{array}$ & $\begin{array}{l}\text { with constructivist approach, it can be said that one of the methods that support } \\
\text { the participation of students in teaching process through hands-on experience is } \\
\text { drama method. The purpose of this research is to put proth an proposal in order } \\
\text { tol et primary school teachers teach the social studies lesson course subjects more } \\
\text { effectively by using drama methods and techniques. It is desired the place and } \\
\text { importance of the used methods and the techniques in children's education and } \\
\text { training lives and in the contents of social studies lesson schedule. In the research; } \\
\text { the lesson plans related to application of the techniques in drama will be prepared } \\
\text { by considering the subjects in "My School Excitement", "My Nonesuch Family" } \\
\text { and "Yesterday, Today, Tomorrow" themes in Social Studies Lesson guide of the } \\
2 \text { nd class (which has been prepared for } 2014 \text { - } 2015 \text { school year and approved by } \\
\text { Ministry of National Education) in the light of form semi-structured by literature } \\
\text { scanning and scanning of thesis, articles, boks and similar documentary printed } \\
\text { references and of gathered teacher opinions. Based on the opinions of the teachers- } \\
\text { whose lesson plans prepared at the end of the research has been taken-, the results } \\
\text { will be discussed in the light of literatures. }\end{array}$ \\
\hline
\end{tabular}

1 Yrd. Doç. Dr., Dokuz Eylül Üniversitesi Eğitim Fakültesi İlköğretim Bölümü, E-posta: hadiye2000@yahoo.com

2 Sinıf ögretmeni, Beylerbeyi İlkokulu, E-posta: deryaav_9@hotmail.com 


\section{Giriş}

Geleceğin çocuklarından beklenen üretken, eleştirel, bağımsız ve yaratıcı düşünebilen, özgün fikirler oluşturabilen, muhakeme yapabilen, problemlere çözüm üretebilen, bireysel farklılı̆̆ını yansıtabilen bir nesil meydana getirmeleri ve toplumsallaşmalarıyla birlikte yaşadıkları yerin kültürünü ve tarihini tanımalarını sağlayarak, toplumdaki rollerinin gerektirdiği davranışları kazandırmak eğitim kurumlarının görevleridir. Bu işlevi yerine getiren okullar bireylerin mutlu ve üretken olmasını sağlar. Böyle bir yaşam tarzı oluşturabilme ve geliştirebilmede Hayat Bilgisi eğitimi belirleyici ve işlevsel bir öneme sahiptir (Meb, 2009).

Hayat Bilgisi dersinin amac1, öğrencilere önemli sosyal becerileri kazandırarak toplumsallaşmalarını sağlamak ve iyi bir vatandaş olarak yetiştirebilmektir. Ayrıca bu ders ile öğrencilerin başkalarıyla daha rahat ve sağliklı ilişkiler kurması ve toplumsallaşması sağlanır (Koç, 2013). Dramada da sosyal rollerin canlandırılması söz konusu olduğundan, kendisini başkalarının yerine koymayı deneyen çocuk, oyunlardaki rolleri toplumsal konulara uygun olarak şekillendirmeye çalışır ve böylece yeteneklerini geliştirmiş olur (Çağlaroğlu, 1999, s.21).

Dramada çocuklar yaşamlarına karmaşık gelen yetişkin dünyasını anlayabilmekte, çevrelerini tanıyarak insanlarla ilişki kurabilmekte ve uyum gösterebilmektedirler. Çocukların anne, baba, şoför, pilot gibi yetişkin rollerini benimseyerek hayal güçlerini yaratıcı biçimde kullanarak oynamalarıyla bu yöntemin öğrencilerin bilişsel gelişimlerine olan katkısı göz ardı edilmemelidir. Arkadaşlarıyla işbirliği halinde olan çocuk, nesne ve olaylar karşısındaki tavır ve hareketleri ve en sonunda yaptığı değerlendirmeler ile bilişsel gelişimini olumlu yönde gösterebilmektedir. Ayrıca drama yöntemi "soyut ders konularını somutlaştırarak çocuklarda ögrenmenin kalıcı olmasına yardımcı olur" ve içe dönük çocukların arkadaşlarıyla kaynaşarak bastırılmış duygularını dışa vurup rahatlayarak çevresiyle iyi bir iletişim kurmasını sağlar (Aral ve diğerleri, 2000, s. 40-41). Buradan yola çıkarak "hem bir ögretim yöntemi, hem bir disiplin, hem de sanat eğitimi aracı olan drama, anlatımsal yaratıcılığı, çocuğun toplumsallaşmasını ve bilinçlenmesini geliştiren yardımcı bir alandır” (Aral ve diğerleri, 2000, s.40).

Eğitimde dramanın amac1; bir kavramın, bir ders konusunun, bir metnin daha iyi anlaşılır kılınması, birey ve küme tarafından özümsenip içsel yaşantıya dönüşmesi, gözden geçirilerek, üzerinde düşünülerek çalışılmasıdır (Okvuran, 2002). Ayrıca eğitimde dramaya yer verilmesiyle eğlenerek öğrenme sürecine katılan çocukların kendini gerçekleştirebilen, yaratıcı, dürüst, iletişime açık ve bağımsız bireyler olması hedeflenir. (Üstündağ, 1994). Dramadaki öğrenmenin, bilgilerin yeni bir bakış açısıyla değerlendirilerek bir ders konusunun çocuk ve gençlerin katılımıyla yeni bilgi ve deneyimlerin elde edilebildiği bir tür yeniden yapılanma olduğu belirtilebilir. Bu esnada doğal olan bu süreçlerde çeşitli disiplinlerden gelen bilgilerin de işlenebilirliği göz önüne alınırsa eğitimde dramanın önemli bir yere sahip olduğu ve yaratıcıllı̆̆ geliştirebilen yöntemlerden biri olduğu tekrar belirtilebilir.

Öğretim sürecinde drama tekniklerinin her öğretmen tarafından farklı biçimlerde kullanabilmesi ile birlikte ders müfredatlarının öğretilmesinde elverişli bir yöntem olduğu söylenebilir. Hayat Bilgisi dersinin konu itibariyle esnek ve konuların birbiriyle iç içe bir ders olduğu düşünülürse, drama yönteminin bu ders esnasında kullanılması eğitim kalitesinin olumlu yönde gelişmesi açısından etkili olabilir. 
Hayat Bilgisi dersinin de yaşama yakınlığı itibariyle yaparak ve yaşayarak öğrenmeyi desteklemesiyle öğrencilerde daha kalıcı izli davranışlar meydana getirdiği düşünülerek ilkokullarda bu dersin yapılandırmacı yaklaşımla işlenmesinin bir gereksinim olmasıyla birlikte bu yaklaşımda üründen çok sürece verilen önem göz önüne alındığında Hayat Bilgisi dersinin yaşamla doğrudan ilişkili olmasının drama yöntemiyle işlenmesi bakımından önem arz ettiği görülmektedir.

\section{Amaç}

$\mathrm{Bu}$ araştırmanın amacı ile alan yazın incelenerek ve drama yaşantısı geçirmiş öğretmen görüşleri alınarak ilkokul 2. Sınıf Hayat Bilgisi dersinin drama yöntemi ile öğretimine ilişkin bir uygulama önerisi ortaya koyulmuştur.

\section{Yöntem}

Çalışma betimsel tarama modelindedir. Veriler konu ile yazılı ve basılı tez, kitap ve diğer yayınlar ile öğretmen görüşlerinin yer aldığı yarı yapılandırılmış bilgi formu ile toplanmıştır. Çalışma sonucunda hazırlanan ders planları nitel veri analiz tekniğine göre incelenen öğretmen görüşlerine ve tarihsel yönteme göre seçilen ilgili alan yazın ışığında tartışılarak öneriler sunulmuştur.

\section{Çalışma Grubu}

Çalışma grubu araştırmacı tarafindan tarihsel yönteme göre; yazılı belgelere dayanarak izleyen ve inceleyen yaklaşım ile belirlenmiş tezler, kitaplar, Hayat Bilgisi dersi resmi müfredat, dergiler, sempozyumlar, konferans bildirileri ve internet üzerinden sorgulamalar ile kolay ulaşılabilir örnekleme göre seçilen ilkokullarda sınıf öğretmenliği yapmış, drama yaşantısına sahip İzmir ve Denizli ilinde görev yapan 35 (15 erkek ve 20 kadın) sınıf öğretmeninden oluşmaktadır.

\section{Veri Toplama Yöntemleri ve Çözümleme Teknikleri}

Drama, drama yönteminin çeşitli derslerle olan ilişkisi ve Hayat Bilgisi dersi ile ilgili bilgilere ulaşabilmek için kütüphanelerden, Yüksek Öğretim Kurumunun internet sitesinden (http:/ tez.yok.gov.tr), sanal kütüphaneden (www.mkutup.gov.tr) ve sahaflardan yararlanılarak ulaş1labilen tezlere, makalelere, kitaplara, Hayat Bilgisi dersi resmi müfredatına, dergilere, sempozyumlara, konferans bildirilerine ve elektronik ortamdaki kaynaklara başvurulmuştur. Bu kaynaklar tarihsel yöntem ile incelenmiştir.

Drama yönteminin Hayat Bilgisi dersinde kullanılmasına ilişkin öğretmen görüşlerinin alındığı yarı yapılandırılmış bilgi formunun geliştirilmesi aşamasında 4 öğretmen ve 1 uzman görüşüne başvurulmuştur. Öneriler doğrultusunda gerekli düzeltmeler ve eklemeler yapıldıktan sonra bilgi formuna son hali verilmiştir. Bilgi formu nitel veri analiz tekniğine göre incelenerek, sorulara içerik analizinin bir takım aşamaları uygulanmıştır. Bunlar verilerin kodlanması, temaların bulunması, verilerin kodlara ve temalara göre organize edilip tanımlanması, bulguların yorumlanmasıdır (Yıldırım ve Şimşek, 2011, s. 162-174). Sorular araştırmacı ve 4 öğretmen tarafından bölümlere ayrılmış ve isimlendirilerek kodlanmıştır. Benzer anlama sahip olanlar aynı kodlarla isimlendirilmiş, verilerin tümünde benzer olanlar ilişkilendirilerek temalar oluşturulmuş ve kodlar arasındaki ortak yönler kategorize edilmiştir. Veriler kodlara göre düzenlenmiş, yorum yapılarak tanımlanmıştır. 


\section{Bulgular}

Çalışmanın bu bölümünde öğretmenlerin yarı yapılandırılmış bilgi formu sorularına verdikleri yanıtlar, bu yanıtlara ilişkin yüzde-frekans değerleri ve hazırlanan ders planlarına yer verilmişstir.

Tablo 1. "Uygulanmakta olan Hayat Bilgisi ders programı ve ögretim yöntemleri hakkında görüşleriniz nelerdir?” sorusuna ilişkin öğretmen görüşleri ve yüzde-frekans değerleri

\begin{tabular}{|c|c|c|c|c|c|}
\hline \multirow[t]{2}{*}{ Kategori } & \multirow[t]{2}{*}{ Örnek Cümleler } & \multicolumn{2}{|c|}{$\begin{array}{l}\text { Bahseden Sınıf } \\
\text { Öğretmeni }\end{array}$} & \multicolumn{2}{|c|}{$\begin{array}{c}\text { Dile Getirilme } \\
\text { Sıklığı }\end{array}$} \\
\hline & & f & $\%$ & f & $\%$ \\
\hline $\begin{array}{l}\text { Hayat Bilgisi ders } \\
\text { programının yetersiz } \\
\text { görülmesi }\end{array}$ & $\begin{array}{l}\text { "Müfredat açısından } \\
\text { yetersiz bir } \\
\text { program." }\end{array}$ & 14 & 40 & 36 & 50 \\
\hline $\begin{array}{l}\text { Hayat Bilgisi ders } \\
\text { programındaki konuların } \\
\text { yeterince iyi hazırlanmadığı }\end{array}$ & $\begin{array}{l}\text { "Çok basit konularla } \\
\text { bile hedefe } \\
\text { ulaşamayan bir } \\
\text { programdır. }\end{array}$ & & & & \\
\hline $\begin{array}{l}\text { Programdaki etkinliklerin } \\
\text { yetersiz olduğu }\end{array}$ & $\begin{array}{l}\text { "Etkinlikler } \\
\text { çocukların } \\
\text { seviyelerine uygun } \\
\text { değil." }\end{array}$ & & & & \\
\hline $\begin{array}{l}\text { Hayat Bilgisi dersinde } \\
\text { kullanılan yöntem ve } \\
\text { tekniklerin yetersiz olduğu }\end{array}$ & $\begin{array}{l}\text { “Öğretim yöntemleri } \\
\text { çok siradan. }\end{array}$ & & & & \\
\hline $\begin{array}{l}\text { Soru cevap yönteminine s1k } \\
\text { başvurulması }\end{array}$ & $\begin{array}{l}\text { “Öğretim yöntemleri } \\
\text { olarak daha } \\
\text { çok soru cevap } \\
\text { ve düz anlatım } \\
\text { uygulanmaktadır. }\end{array}$ & & & & \\
\hline $\begin{array}{l}\text { Hayat Bilgisi programının ve } \\
\text { bu derste kullanılan yöntem ve } \\
\text { tekniklerin yeterli görülmesi }\end{array}$ & $\begin{array}{l}\text { Çocuğun severek } \\
\text { çalışacağ } \text { şekilde } \\
\text { hazırlanmışırı." }\end{array}$ & 21 & 60 & 27 & 37.5 \\
\hline $\begin{array}{l}\text { Hayat Bilgisi dersi } \\
\text { programındaki konuların iyi } \\
\text { hazırlanmış olduğu }\end{array}$ & $\begin{array}{l}\text { "Konu seçimi } \\
\text { seviyeye uygun olarak } \\
\text { hazırlanmıştır." }\end{array}$ & & & & \\
\hline Etkinliklerin yeterli olduğu & $\begin{array}{l}\text { "Programda bulunan } \\
\text { etkinlikler yeterlidir." }\end{array}$ & & & & \\
\hline $\begin{array}{l}\text { Hayat Bilgisi dersi } \\
\text { programındaki kazanımların } \\
\text { nasıl olduğu }\end{array}$ & $\begin{array}{l}\text { "Programın öğretim } \\
\text { yöntemleri iyi } \\
\text { hazırlanmıştır." }\end{array}$ & & & & \\
\hline
\end{tabular}


Bilgi formunda öğretmenlere yöneltilen "Uygulanmakta olan Hayat Bilgisi ders programı ve öğretim yöntemleri hakkında görüşleriniz nelerdir?” sorusuna öğretmenlerin verdikleri cevaplar doğrultusunda \%40’1 Hayat Bilgisi ders programının ve ders anında kullanılan yöntem ve tekniklerin yetersiz olduğunu, programdaki konuların yeterince iyi hazırlanmadığını, etkinlik sayısının az ve soru cevap yönteminin de sık kullanıldığını dile getirmişlerdir. Öğretmenlerin \%60’1 ise programın yeterli, konuların iyi hazırlanmış, seçilen kazanımların öğrencilere uygun ve ders anında kullanılan yöntem ve tekniklerin yeterli olduğunu ifade etmişlerdir.

Programı yetersiz gören öğretmenler programdaki soyut kavramların çıkarılmasını, ders programının işitsel ve görsel ögelerle zenginleştirilmesini istemektedirler. Çok basit konularda bile hedefe ulaşamadıklarını belirterek konu dağılımlarının ve etkinliklerin çocukların seviyelerine uygunluğu açısından iyi olmadığını, ders saatlerinin kısa tutulduğunu ve yöntemler arasında ezber yöntemine daha çok başvurulduğunu belirtmişlerdir. Tercih edilen diğer yöntemlerden anlatım ve soru cevap yöntemi yerine öğrenciyi sürece katabilen yöntemleri örneğin yaparak yaşayarak tercih etmelerinin daha iyi olacağını önermişlerdir.

Hayat Bilgisi dersi yaşama yakınlığı itibariyle yaparak ve yaşayarak öğrenmeyi desteklemesiyle birlikte öğrencilerde daha kalıcı izli davranışlar meydana getirilebilir. Bu bağlamda ilkokullarda Hayat Bilgisi dersinin yapılandırmacı yaklaşımla işlenmesinin bir gereksinim olduğu söylenebilir. Yapılandırmacı yaklaşımda üründen çok sürece verilen önem göz önüne alındığında Hayat Bilgisi dersinin yaşamla doğrudan ilişkili olması ve drama yönteminin soyut ders konularını somutlaştırarak çocuklarda öğrenmenin kalıcı olmasına yardımcı olması ve içe dönük çocukların arkadaşlarıyla kaynaşarak bastırılmış duygularını dışa vurup rahatlayarak çevresiyle iyi bir iletişim kurmasını sağlaması (Aral ve diğerleri, 2000) düşünülürse Hayat Bilgisi dersinde bu yöntemin kullanılmasının yararlı olacağı belirtilebilir.

Programı yeterli gören öğretmenler çocuğun severek çalışabileceği ve yapılandırmacı öğrenme yaklaşımı doğrultusunda düzenlenen programın çocukların güncel hayatlarından örneklemeler içerdiğini, 1. sınıf öğrencileri için görsel okumaya uygun hazırlandığını düşünmektedirler. Konular için yeterli zamanın verildiğini, kazanım sürelerinin dengeli dağıtıldığını ve etkinliklerin öğrencilere uygunluğundan bahsetmişlerdir. Ayrıca öğretmenlerin ilkokulda öğrencilerde somut düşünce varlığ1 ile çeşitli duyu organlarını harekete geçirecek yöntem ve teknikleri kullandıklarını vurgulamışlardır. Dramanın, içinde eylem olan, bir ya da birden çok insanın birbirleriyle, doğayla ya da başka nesnelerle etkileşerek yaşadıkları içsel ve dışsal devinimler ve onların yaşam durumlarını geniş ölçüde içeren etkinlikler olduğunu vurgulanırsa dramanın bu derste tercih edilmesinin yararı belirtilebilir.

Bilgi formunun ikinci sorusu olan "Drama yönteminin Hayat Bilgisi dersinde uygulanıp uygulanmadığı hakkında görüşleriniz nelerdir? "sorusuna ilişkin öğretmen görüşleri ve yüzdefrekans değerleri tablo 2'de gösterildiği gibidir. 
Tablo 2. "Drama yönteminin Hayat Bilgisi dersinde uygulanıp uygulanmadiğı hakkında görüşleriniz nelerdir? ”sorusuna ilişkin ögretmen görüşleri ve yüzde-frekans değerleri

\begin{tabular}{|c|c|c|c|c|c|}
\hline \multirow[t]{2}{*}{ Kategori } & \multirow[t]{2}{*}{ Örnek Cümleler } & \multicolumn{2}{|c|}{$\begin{array}{c}\text { Bahseden Sınıf } \\
\text { Öğretmeni }\end{array}$} & \multicolumn{2}{|c|}{$\begin{array}{c}\text { Dile Getirilme } \\
\text { Sıklığı }\end{array}$} \\
\hline & & f & $\%$ & f & $\%$ \\
\hline $\begin{array}{l}\text { Drama yönteminin } \\
\text { Hayat Bilgisi } \\
\text { dersinde uygulanması }\end{array}$ & $\begin{array}{l}\text { "Drama yöntemi Hayat Bilgisi dersinde } \\
\text { kullanılmaktadır. Tüm grupla drama, } \\
\text { geriye dönüş, yarım kalmış materyaller, } \\
\text { doğaçlama, mektuplar ve öğretmenlerin } \\
\text { rol alması teknikleri konu ve dramaya } \\
\text { uygun olarak kullanılmaktadır.” } \\
\text { "Uygulamaya müsait bir yöntem. } \\
\text { Kukla ve çeşitli yöntemlerle } \\
\text { uygulanmaktadır.” }\end{array}$ & 15 & 42.8 & 31 & 42.4 \\
\hline $\begin{array}{l}\text { Drama yöntemi } \\
\text { uygulanmasının } \\
\text { tercih edilme } \\
\text { nedenleri }\end{array}$ & $\begin{array}{l}\text { "Sosyal becerileri ve iletişimi } \\
\text { gerçekleştirmesi açısından } \\
\text { uygulanıyor." } \\
\text { "Arkadaşlarının karşısında oynadığı } \\
\text { rolü ile çocuğun farkındalık düzeyi } \\
\text { arttığı için uygulanıyor." } \\
\text { "Konuların işlenişine göre zaman } \\
\text { zaman başvurulan bir yöntemdir." }\end{array}$ & & & & \\
\hline $\begin{array}{l}\text { Drama yönteminin } \\
\text { Hayat Bilgisi } \\
\text { dersinde } \\
\text { uygulanmaması }\end{array}$ & $\begin{array}{l}\text { "Drama yönteminin kullanımı ile } \\
\text { ilgili öneriler getirilmekte fakat } \\
\text { Hayat Bilgisi dersinde tam anlamıyla } \\
\text { uygulanmamaktadır." }\end{array}$ & 20 & 57.1 & 30 & 41.09 \\
\hline $\begin{array}{l}\text { Drama yönteminin } \\
\text { uygulanmamasının } \\
\text { nedenleri }\end{array}$ & $\begin{array}{l}\text { "Drama edilecek olaylara ait } \\
\text { araç gereçlerin az olması, } \\
\text { eğitim sistemimizin giderek } \\
\text { ezbere dayatılması uygulamayı } \\
\text { engellemektedir." } \\
\text { "Konulara verilen ders saati yetersiz } \\
\text { olduğu için uygulamada bazen güçlük } \\
\text { çekilmektedir. Materyal olmadığı için } \\
\text { uygulamada eksiklik yaşanmaktadır." }\end{array}$ & & & & \\
\hline
\end{tabular}


Bilgi formunda öğretmenlere yöneltilen "Drama yönteminin Hayat Bilgisi dersinde uygulanıp uygulanmadiğı hakkında görüşleriniz nelerdir?” sorusuna öğretmenlerin verdikleri cevaplar doğrultusunda öğretmenlerin \%42.8'i okullarda drama yönteminin Hayat Bilgisi dersinde uygulandığını belirtirken \%57.1'inin ise uygulanmadığını belirtmişlerdir.

Drama yönteminin Hayat Bilgisi dersinde uygulandığını düşünen öğretmenler öğrencinin merkezde tutulduğu bu yöntemin uygulanma aşamasında tıkanıklı yaşanması, rollerin canlandırılamaması gibi durumlarda öğretmene ihtiyaç duyulmasından başka her açıdan faydalı bulmaktadırlar. Ders esnasında tüm grupla drama, geriye dönüş, yarım kalmış materyaller, doğaçlama, mektuplar, öğretmenin rol alması ve kukla gibi tekniklerinin kullanıldığını dile getirirken kılavuzda fazla drama etkinliğinin olmamasından şikayetçidirler.

Öğretmenlerin genelde bu yöntemi tercih etme nedenleri; sosyal becerileri ve iletişimi gerçekleştirebilmesi, arkadaşlarının karşısında oynadığı rolü ile çocuğun farkındalık düzeyinin artması, doğaçlama ile dersin zevkli hale gelmesi, yaparak yaşayarak öğrenmeyi sağlaması ve öğrenmeyi uygulamalı olarak hızlandıran bir yöntem olmasına dayanmaktadır.

Sınıfta dramatize edilecek olaylara ait araç ve gereçlerin az olması, konulara verilen ders saatlerinin yetersiz oluşu, öğretmenlerin yeterli drama yaşantısı geçirmemiş olması, programın dramaya yönelik hazırlanmayışı ve sınıfta disiplin problemi yaratabileceği gibi durumları düşünen öğretmenler dramayı Hayat Bilgisi dersinde uygulamadıkları gözlenmiştir.

Tablo 3. "Drama yöntem ve tekniklerinin Hayat Bilgisi dersinde kullanılabilirliği hakkında görüşleriniz nelerdir?” sorusuna ilişkin öğretmen görüşleri ve yüzde-frekans değerleri

\begin{tabular}{|c|c|c|c|c|c|}
\hline \multirow[t]{2}{*}{ Kategori } & \multirow[t]{2}{*}{ Örnek Cümleler } & \multicolumn{2}{|c|}{$\begin{array}{c}\text { Bahseden } \\
\text { SınıfÖğretmeni }\end{array}$} & \multicolumn{2}{|c|}{$\begin{array}{c}\text { Dile Getirilme } \\
\text { Sıklığı }\end{array}$} \\
\hline & & f & $\%$ & f & $\%$ \\
\hline $\begin{array}{l}\text { Yaparak yaşayarak öğrenilmesi } \\
\text { gerektiği düşünülen ve hayatın } \\
\text { içinden gelen Hayat Bilgisi } \\
\text { dersinde drama yöntem ve } \\
\text { tekniklerinin uygulanabilir } \\
\text { olması }\end{array}$ & $\begin{array}{l}\text { "Yaparak yaşayarak öğrenilmesi } \\
\text { gereken bir ders olduğu için } \\
\text { uygulanabilir." }\end{array}$ & 14 & 40 & 36 & 50 \\
\hline $\begin{array}{l}\text { Drama yöntem ve tekniklerinin } \\
\text { tam anlamıyla uygulanması için } \\
\text { yerine getirilmesi gereken şartlar }\end{array}$ & $\begin{array}{l}\text { Drama yöntem ve tekniklerinin } \\
\text { etkin ve verimli bir şekilde } \\
\text { uygulanabilmesi için } \\
\text { öğretmenlerin hizmet içi } \\
\text { eğitime alınması gereklidir.” }\end{array}$ & 12 & 34.2 & 11 & 18.3 \\
\hline $\begin{array}{l}\text { Drama yöntem ve tekniklerinin } \\
\text { kullanılması ile daha kalıcı } \\
\text { öğrenmelerin meydana gelmesi }\end{array}$ & $\begin{array}{l}\text { "Drama yöntem ve tekniklerinin } \\
\text { derste kullanımı öğrencinin } \\
\text { yaparak ve yaşayarak } \\
\text { öğrenmeleri noktasında daha } \\
\text { kalıcı öğrenmelerine katkıda } \\
\text { bulunmaktadır." }\end{array}$ & & & & \\
\hline
\end{tabular}




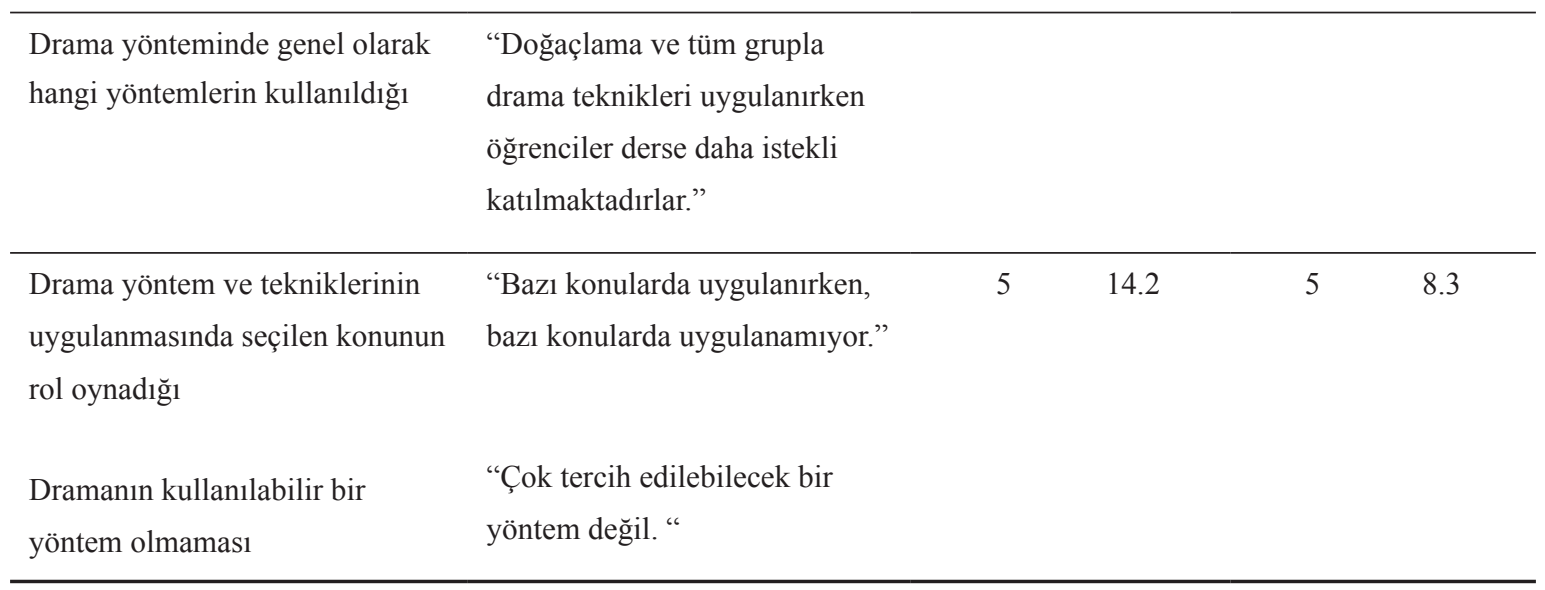

Bilgi formunda öğretmenlere yöneltilen "Drama yöntem ve tekniklerinin Hayat Bilgisi dersinde kullanılabilirliği hakkında görüşleriniz nelerdir?" sorusuna öğretmenlerin verdikleri cevaplar doğrultusunda öğretmenlerin \%85.7'si yaparak yaşayarak öğrenilmesi gerektiği düşünülen ve hayatın içinden gelen Hayat Bilgisi dersinde drama yöntem ve tekniklerinin uygulanabilir olduğunu düşünmektedir.

Öğretmenlerden \%34.2'si drama yöntem ve tekniklerinin tam anlamıla uygulanabilir olması için bazı şartların iyileştirilmesi gerektiğini ve drama yöntem ve tekniklerinin kullanılması ile daha kalıcı öğrenmelerin meydana geldiğini, ders esnasında belli başlı drama tekniklerinin sıç̧a kullanıldığını ve uygulamasında seçilen konularında önemli olduğunu belirtmişlerdir.

Öğretmenler bu dersin yaparak yaşayarak öğrenilmesi gerektiğini, çocukların sürece duygularını katarak dersi daha verimli hale getirdiklerini ve konuların gerçek yaşama yakın olması ile dramanın Hayat Bilgisi dersinde uygulanabilir bir yöntem olduğunu ifade etmişlerdir. Fakat bunun için öğretmenlerin hizmet içi eğitime tabi tutulmasını, okullarda drama odalarının hazırlanmasını, mevcut sınıf sayısının düşürülmesini ve uygun materyallerin sağlanması ile bu yöntemin daha verimli kullanılabileceğini önermektedirler. $\mathrm{Bu}$ yöntemin kullanılması ile öğrencinin yaparak yaşayarak öğrenmeleri noktasında özgüvenlerinin gelişimine ve daha kalıcı öğrenmelerine katkıda bulunacağına inanan öğretmenler ders anında doğaçlama, tüm grupla drama teknikleri uygulanırken öğrencilerin daha istekli katılımlarını göz önüne alarak dramanın uygulanabilir bir yöntem olduğunu dolaylı olarak vurgulamışlardır. Öğretmenlerden \%14.2'si ise dramanın kullanılabilir bir yöntem olmadığını ifade etmişlerdir. 
Tablo 4. "Konu ile ilgili diğer düşünce ve görüşleriniz varsa lütfen yazınız." sorusuna ilişkin ögretmen görüşleri ve yüzde-frekans değerleri

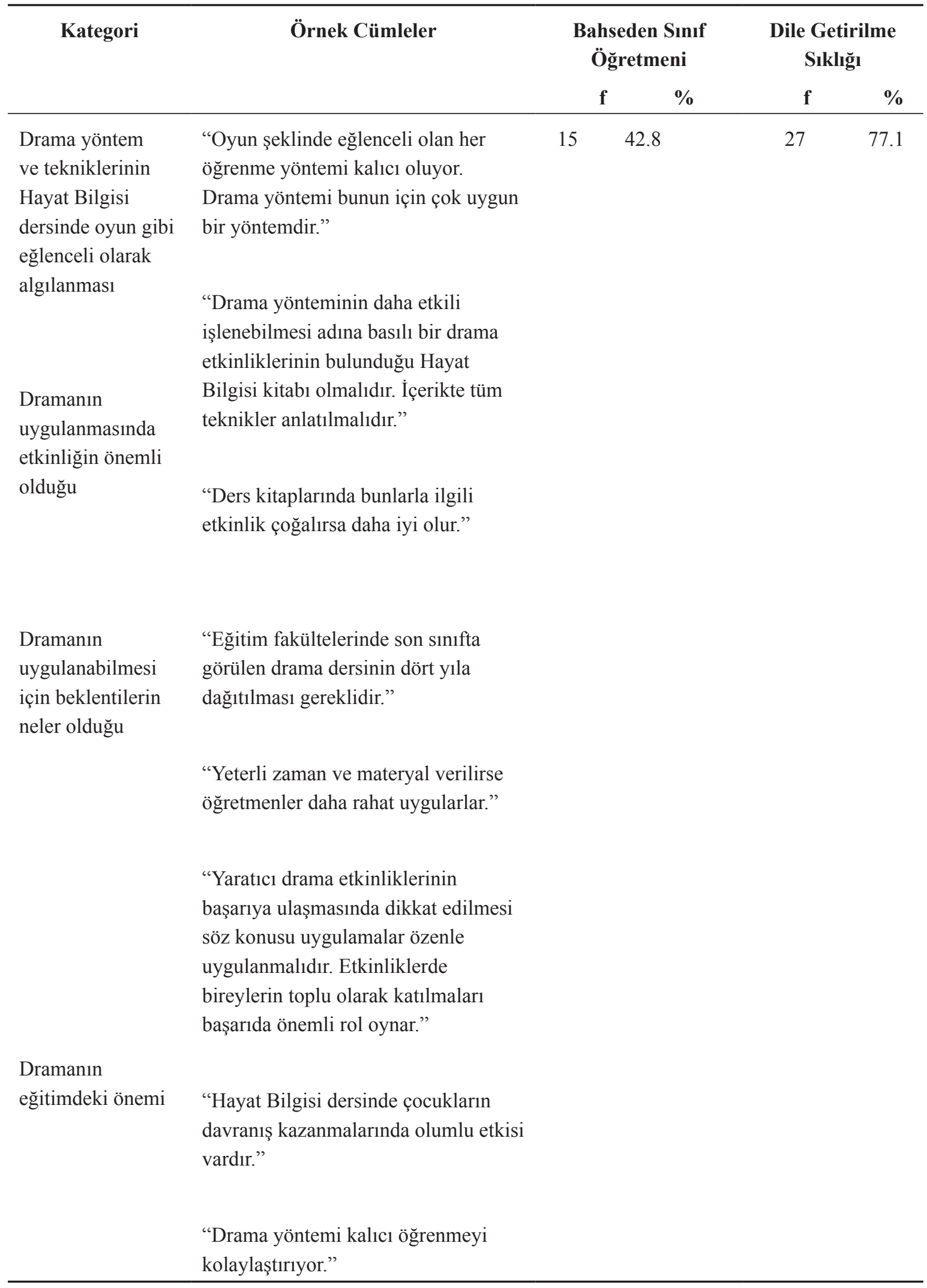


Bilgi formunda öğretmenlere yöneltilen "Konu ile ilgili diğer düşünce ve görüşleriniz varsa lütfen yazınız." sorusuna öğretmenlerin verdikleri cevaplar doğrultusunda öğretmenlerin \%42.8'i drama yöntem ve tekniklerinin Hayat Bilgisi dersinde oyun gibi eğlenceli algılandığını, dramada kullanılan etkinliğin önemli ve dramanın uygulanmasında bazı beklentilerin olduğunu belirterek dramanın eğitimdeki öneminden bahsetmişlerdir.

Uygulama aşamasında etkili bir süreç geçirilmesi için basılı bir drama etkinliklerinin olduğu Hayat Bilgisi kitabına ihtiyaç duymakla birlikte bu kitaptaki etkinliklerin öğretmenlere drama yönteminin kullanılması adına rehberlik edecek bilgiler çerçevesinde hazırlanması gerektiğini belirten öğretmenler, eğitim fakültelerinin son sınıfında görülen bu dersin dört yıla dağıtılmasını, sınıflarda eğitim için yeterli zaman ve materyalin verilmesini önermektedirler. Dramanın eğitimdeki öneminin kalıcı öğrenmeyi sağlaması olduğu belirtilen görüşlerde yöntemin çocuklarda olumlu davranış kazandırması ve sürece toplu olarak katılmalarını sağlaması ile başarılarının yükselebileceğine ulaşılabilir. Görüş alınan öğretmenlerden yirmi (20)'si ise herhangi bir görüş bildirmemiştir.

\section{Tartışma ve Sonuç}

Ulaşılabilen alan yazında Hayat Bilgisi dersinin yaşamın içinden gelen bir ders olduğuna, yapılandırmacı yaklaşımın temeli yaparak yaşayarak öğrenmeyi destekleyen drama yönteminin bu derste uygulanmasına ilişkin öğrenciler üzerinde olumlu etkilerinin gözlemlendiği çalışmalara, dramanın birçok alanda etkisine ve Hayat Bilgisi dersinin çocukların yaşamı algılamalarında önemine dair bilgilere rastlanmıştır.

İncelenen kaynaklara göre yaşamın içinden olan Hayat Bilgisi dersinde ilkokul öğrencilerinin somut yollarla deneyim geçirmeleri önemli sayılabilir. Piaget'e göre bilişsel gelişim aşamalarından somut işlemler döneminde (7- 11 yaş) olan 2. sınıf öğrencileri, somut nesneler ile ilgili problemler çözebilmekte ancak soyut işlemler yapamamaktadırlar (Akt. Kılıç ve Sağlam, 2009:33). Bu dönem çocuklarının bilişsel gelişimleri olayları diğer insanların gözüyle görmesi ile başlayarak, sınıflandırma, cinsiyet, düş ve gerçek ayrımı gibi konularda temel değişiklikler göstermesiyle devam etmektedir (Ed.Yeşilyaprak, 2002). Bu bağlamda, öğrencilerin yaparak yaşayarak deneyim geçirmelerinin kalıcı öğrenmelerini sağlayacağı düşünülerek ders esnasında drama yöntemi ve teknikleri kullanımının yararlı olacağı ile birlikte öğrencilerin karşılaşacağı nesneler ve olaylar ile doğru değerlendirmelere ulaşarak bilişsel açıdan olumlu yönde gelişme gösterecekleri belirtilebilir. Drama ile sadece fiziksel değil sosyal gelişimlerine de katkısı olduğunu söylemek mümkündür. Bu dönem öğrencileri için akran ilişkilerinde arkadaşları tarafından değerlendirilmesi önem taşıdığından olumlu ilişkilerin kurulabileceği etkinlikler hazırlanmasının önemi dile getirilebilir. Ayrıca eğitim öğretim sürecinde uygulanan etkinliklerin öğrencilerin kas gelişimini hızlandırması ile dramadaki hareketlilik solunumlarını, dolaşımlarını ve sindirim sistemlerini etkileyerek salgı bezlerinin daha fazla salg1 yapmasını sağlayarak öğrencilerin fiziksel gelişimini olumlu yönde etkileyebilir.

Dramanın öğrencilerin bilişsel, fiziksel ve sosyal gelişimlerine olumlu katkısı düşünülerek bu bölümde, eğitimde çağa uygun bir yaklaşım olan yapılandırmacı kuramın temelinde, Hayat Bilgisi dersi ve dramanın tarihsel gelişimi ve eğitimde önemi üzerinde durularak, drama yöntemi ve teknikleri belirtilerek, ilkokul 1., 2. ve 3. sınıflarda eğitim vermiş tecrübeli öğretmenlerin görüşleri alınarak, 2. Sınıf Hayat Bilgisi ders kitabında bulunan “Okul Heyecanım”, "Benim, Eşsiz Yuvam” ve "Dün, Bugün, Yarın” temalarında yer alan konuların ders esnasında uygulanabilecek drama yöntemine dayalı bir uygulama önerisi ile hazırlanmış ders planları, genel bir yorum yapılarak tartışılmıştır. 
Alan yazın incelenmesinden sonra uygulanan form ile alınan görüşlerde Hayat Bilgisi ders programı ve yöntemi, dramanın Hayat Bilgisi dersinde uygulanıp uygulanmadığı ve kullanılabilirliğine ilişkin sorulara dair cevaplar nitel veri analiz tekniği ile incelenmiştir. Öğretmen görüşlerinde sosyal becerileri ve iletişimi gerçekleştirebilmesi, arkadaşlarının karşısında oynadığı rolü ile çocuğun farkındalık düzeyinin artması, doğaçlama ile dersin zevkli hale gelmesi ve yaparak yaşayarak öğrenmeyi sağlaması bakımından drama yöntemi kullanımının tercih edildiği gözlenmiştir. Alan yazında yer alan Kara ve Çam (2007)'ın araştırması, drama yönteminin gelişim ve öğrenme dersinde öğrencilerin grupla bir işi yapma ve yürütme, ilişkiyi başlatma ve sürdürme ile kendini kontrol etme becerileri üzerinde etkili olduğunu ortaya koyması bakımından öğretmenlerin drama yöntemini kullanımına ilişkin görüşlerini destekler niteliktedir.

Sınıflarda dramatize edilecek olaylara ait araç ve gereçlerin az olması nedeni ile bazı öğretmenler drama yöntemini kullanamadıklarını belirtmişlerdir. Halbuki drama sürecinde her türlü eşya kullanılabilir. Yöntemin bu gerekçeden dolayı kullanılamaması üzüntü verici bir durumdur. Alan yazında yaratıcı dramada her çeşit araç- gerecin kullanılabilirliğinden bahsedilmektedir. Fotoğraf, resim kağıdı, poster, kukla, boya, oyuncak, eskimiş giysi, resim ve ev eşyaları gibi... Bu araç ve gereçler amaçları dışında kullanılabilir. Örneğin masa örtüsü pelerin, tahta silgisi mikrofon ya da cep telefonu olabilir (Nas, 2006, s.175). Drama yöntemine ilişkin bilgilerin öğretmenlere aktarılarak bu engelin önüne Milli Eğitim Bakanlığı tarafından planlanacak hizmet içi eğitim ile geçilmesi mümkün olabilir. Ayrıca Adıgüzel'in "Yaratıcı Dramanın Sosyal Bilgiler Öğretiminde Kullanımı" makalesinde öğretmen görüşlerinde belirtilmeyen fakat dile getirilmesinde fayda görülen, okullarda kimi yöneticilerin dramayı tiyatro ile karıştırıp drama öğretmenlerinden tiyatro sergileri yapmalarını istediklerinde öğretmenlerin zorluk yaşadığından bahsedilmiştir. Bu durum da hizmet içi eğitim ile öğretmenlerin dramaya yönelik bilgi eksikliklerinin giderilmesiyle düzeltilebilir. Diğer taraftan konulara ayrılan ders saatlerinin yetersiz olması ve drama yönteminin sınıfta disiplin problemi yaratabileceği gibi durumları düşünen öğretmenlerin bu yöntemi Hayat Bilgisi dersinde kullanmamalarına ilişkin haklılık payı verilebilir.

Öğretmen görüşlerinde drama etkinliklerinin okullarda drama odalarının oluşturularak işlenmesi, öğrencilerin dramayı uygulayacakları rahat bir ortama sahip olabilmeleri adına önem taşıdığı yer almaktadır. Mekan olarak sınıfta sabit sıraların olması drama yöntemi ile işlenen derslerin verimli geçmesini engelleyebileceği ile okullarda drama odalarının bir ihtiyaç olduğu belirtilerek gerekli kaynakların eğitimle ilgili kurumlardan sağlanması ile her okulda bir drama odası oluşturulabilir.

Milli Eğitim Bakanlığı "Drama Dersi Öğretimi Programı" $n$ alanında uzman bir ekip tarafından hazırlanmasını sağlamadığından program içeriğinin doldurulmasında ve Hayat Bilgisi dersine entegre edilmesinde güçlük çekilmektedir (Öztürk, 2010). Öğretmen görüşlerinde de yer alan bu sıkıntının giderilmesi için öğretim programının alanında uzman kişiler tarafından hazırlanması sağlanabilir.

2.sınıf öğrencilerinin drama yöntemini oyun gibi algılaması, yöntemin zihinlerinde kalıcı öğrenmeleri arttırması, drama ile etkinlik sayısının az olması ve incelenen alan yazında Türkçe, Sosyal Bilgiler, Din Kültürü ve Ahlak Bilgisi, Psikoloji ve Matematik derslerine ilişkin drama yöntemi ile hazırlanmış ders planları mevcut iken Hayat Bilgisi dersine ait bulunamaması ve öğretmenlerin görüşlerinde Hayat Bilgisi dersinde drama yöntemi ile hazırlanmış ders planlarına ait bir eserin bulunmadığını belirtmesi böyle bir çalışmanın hazırlanmasına karar verilmesinde etkili olmuştur. 
$\mathrm{Bu}$ çalışmada hazırlanan ders planları öğretmenlerin ders süresinin yetersiz olmasını dile getirmeleri dikkate alınarak planlanmıştır. Tay (2009)'ın aktardığına göre bu dönem öğrencilerinin dikkatlerini uzun süre aynı konuya vermeleri mümkün değildir. Bu nedenle planlar hem öğretmenlerin dersi işleyebilecekleri süre göz önüne alınarak, hem de öğrencilerin ilgilerini maksimum düzeyde çekilebilecek şekilde tasarlanmıştır .

Öğretmenler Hayat Bilgisi dersinde soru cevap yönteminin sık kullanıldığını dile getirerek daha farklı öğretim yöntemlerine başvurulması gerektiğini belirtmişlerdir. Alan yazında yer alan “Hayat Bilgisi Öğretim Rehberi” (Tekışık, 1987) kitabında soru cevap yönteminin, öğrencilerin zihni aktifliğe sevketmesi açısından, temalarda bu yöntemin kullanılmasının öneminden bahsedilmesiyle birlikte çocukların doğasında var olan soru sorma isteğinin köreltilmemesinin ve merak duygularının bastırılmasından çok kazandırılmasının gelecek yaşamlarında onlara faydalı olabilecek bilgilere ulaşmasında yardımcı olacağı belirtilmesinden dolayı öğretmen görüşlerinde yer alan bu öneri dikkate alınmamış ve ders planlarında soru cevap yöntemi kullanılmıştır.

Öğretmenler çocukların somut işlemler döneminde olmaları nedeniyle Hayat Bilgisi ders programında yer alan bazı soyut kavramların çıkarılarak, programın somutlaştırılması için işitsel ve görsel ögelerle zenginleştirilmesini istemelerine ilişkin görüşleri ile ilkokulda öğrencilere somut düşünce varlığ ile çeşitli duyu organlarını harekete geçirecek yöntem ve teknikleri kullandıklarını vurgulamışlardır. $\mathrm{Bu}$ görüşler dramanın, öğrencinin tüm duyularını harekete geçiren bir yöntem ve Hayat Bilgisi dersinde kullanılması açısından uygun olduğunu destekler niteliktedir. Drama yöntemi ile öğretmen rehberliğinde öğrencilere farklı yaşantı ve deneyimlerin kazandırılması mümkündür. Hazırlanan ders planlarında öğrencilerin gözlemlerden, incelemelerden ve olgulardan yola çıkarak genellemelere, ilkelere ulaşması amaçlanarak ezberleme yerine anlayarak öğrenmelerinin sağlanması istenmiştir. Ders planları tanımdan başlanmamış, öğrencilerin tanımlara kendilerinin varması hedeflenmiştir.

Araştırma ile elde edilen bulguların; drama yönteminin Hayat Bilgisi dersinde kullanılabilirliğini etkilemesi, bu ders konularına ait planlarının hazırlanması konusunda yapılacak bilimsel çalışmalara kaynaklık etmesi, öğretmenlerin Hayat Bilgisi dersini işlerken onlara yeni bakış açısı kazandırmasıyla drama yöntemi kullanımlarını arttırması beklenmektedir.

\section{Kaynaklar}

Aral, N., Baran, G. , Bulut, Ş. ve Çimen, S. (2000). Drama (1.bs. ). İstanbul: Ya-Pa Yayıncılık.

Çağlaroğlu, T. (1999). Illköğretim seçmeli drama. Ankara: Yeni Çizgi Yayınları.

Kılıç, D. ve Sağlam, N. (2009). Öğrencilerin mantıksal düşünme yeteneklerinin bazı değişkenler açısından incelenmesi. Ege Ë̆itim Dergisi, 2(10), 23-38.

Koç, İ. (2013). Öğretmenlerin sosyal bilimler dersinde drama yönteminin uygulama ve drama tekniklerine iliş̧kin yeterliliklerinin belirlenmesi. Ahi Evran Üniversitesi Sosyal Bilimler Enstitüsü, Kırşehir.

MEB. (2009). Illköğretim 1, 2 ve 3. sinıflar hayat bilgisi dersi öğretim programı ve kılavuzu. Ankara: MEB Yay.

Nas, R. (2006). Hayat bilgisi ve sosyal bilgiler öğretimi. Bursa: Ezgi Kitabevi.

Okvuran, A.(2002). Drama öğretimi ve dramaya dayalı öğrenme. Öğrenme ve Öğretme 1. Sempozyumu Bildirisi. Ankara Üniversitesi Eğitim Bilimleri Fakültesi.

Öztürk, A. (2010). Yaşamda drama dramada yaşam. Ankara: Naturel Yayıncılık.

Tekışık, H. H. ve Tekışık, B. T. (1987). Hayat bilgisi öğretimi. Ankara: Ege Yayınları.

Üstündağ, T. (1994). Günümüz eğitiminde dramanın yeri. Yaşadıkça Eğitim.

Yeşilyaprak, B. (2002). (Ed.). Gelişim ve öğrenme psikolojisi. Ankara: PegemA Yayıncılık.

Yıldırım, A. ve Şimşek, A. (2011). Sosyal bilimlerde nitel araştırma yöntemleri. Ankara: Seçkin Yayıncılık. 


\section{Ek: Ders Planlart}

\section{Ek 1: Ders Plant-1}

Yer: Sinıf ya da drama odası

Ö̆rrenciler: İlkokul 2. Sinıf

Копи: Kitaplikta neler var?

Tema: Okul Heyecanım

Süre: $40 \mathrm{dk}$.

Yöntem ve teknikler: Rol oynama, öğretmenin rol alması, soru cevap

Araçlar ve gereçler: Kalem

Kazanım:

1. Kaynak kitaplardan nasıl yararlanacağını açıklar ve bunlardan yararlanır.

Öğrenme öğretme süreci: Sınıfa girerken çok dalgın bir biçimde, kitaptan bir şey okuyormuş gibi yapan öğretmen öğrencilerine karşı birkaç dakika ilgisiz kalarak onların dikkatini çekmeye çalışır.

1. Giriş etkinlikleri (Hazırlık): Öğretmen öğrencilere ayağa kalkmalarını ve şu an büyük bir kütüphanede olduklarını söyler. Hepsinin önünde sanki ansiklopedi, dergi, kitap olduğunu, bunları kütüphanenin en üst rafına yerleştirmelerini ister. Öğrenci yere eğilerek kitabı alır gibi yapar ve uzanabildiği yere kadar uzanıp kitabı yerleştirir. Bir dakika boyunca bu hareket uygulanır.

2. Geliştirme etkinlikleri (Canlandırma): Öğretmen tüm öğrencileri tahtaya kaldırır. İçlerinden seçtiği beş öğrenciye ansiklopedi, harita, sözlük, yazım kılavuzu ve atlas rollerini dağıtır. Rolleri tanıtan önceden hazırladığı tanıtıcı kartları öğrencilere verir. Daha sonra gözlerini kapatıp kendilerini dağıtttığı nesneler gibiymiş gibi hissetmelerini ister. Hepsi gözlerini açınca diğer öğrenciler ne işe yaradıkları, neye benzediklerini ile ilgili her türlü soruyu sorarlar. Eğer cevaplayamayan olursa öğretmen oyuna elinde zamanı dondurabilen asası olarak kullandığı kalemi ile melek olarak role girer. Zamanı tahtaya asası ile vurarak dondurur. Hiç kimse kımıldamaz, öğretmen cevabı veremeyen öğrencinin kulağına cevabı fisıldar ve sonra tekrar asasını tahtaya vurarak oyundan çıkar ve oyun kaldığı yerden devam eder. Çalışma öğrenciler arasında roller değiştirilerek birkaç kez tekrarlanır.

3.Sonuç etkinlikleri (Değerlendirme): Öğretmen aşağıdaki soruları sorarak genel bir değerlendirme yapar.

1. Oyunu oynarken neler hissettiniz?

2. En çok hangi rolleri beğendiniz?

3. Kaynakların ne işe yaradığını teker teker kimler anlatmak ister?

Ek 2: Ders Planı-2

Yer: Sinıf ya da drama odası

Öğrenciler: İlkokul 2. Sınıf

Копи: Kimin Yuvası

Tema: Benim Eşsiz Yuvam

Süre: $40 \mathrm{dk}$.

Yöntem ve teknikler: Yürüyerek 1sınma oyunu, rol oynama

Araçlar ve gereçler: Peluş oyuncak

Kazanım:

1. Her canlının bir yuvaya ihtiyacı olduğunu kavrar ve canlıların yuvalarını birbirinden ayırt eder.

Öğrenme öğretme süreci: Öğretmen sınıfa oyuncak pelüş bir hayvanla girerek derse başlar.

1. Giriş etkinlikleri (Hazırlık): Öğretmen elindeki pelüş hayvanın yuvasını kaybettiğini ve annesinin onu çok özlediğini söyler. Öğrencilere bu oyuncak hayvanı yuvasına götürmeleri için zorlu yolda, sanki sırtlarında yük varmış ve çamurdaymış gibi yürümelerini, buraları geçtikten sonra önlerine çıkan ezilmiş domateslerin 
üzerinden dikkatlice geçmelerini ister. Etkinlik öğretmenin "Hayvanın yuvasını buldunuz!” diye seslenmesiyle sona erer. Hayvanı yuvasına ulaştıran öğrenciler kendilerini alkışlarlar.

2. Gelişstirme etkinlikleri (Canlandırma): Öğretmen hayvanların yuvalarına ait olan resimlerin bulunduğu bir posteri tahtaya asar. Daha sonra öğrencilerden gönüllü olanların yedi tanesini tahtaya çıkarır. Arı, kuş, köpek, inek, tavuk, tavşan ve aslan olmak üzere öğrencilere rollerini dağıtır. Aslanın arkadaşlarına onları evinde ziyaret etmek istediğine dair mektup yazmasını söyleyerek kendisi de sanki postacıymış gibi mektubu hayvan arkadaşlarına ulaştıracağını belirtir. Dha sonra öğretmenin yönlendirlmesiylşe arı, kuş, köpek, inek tavuk ve tavşanı canlandıran öğrenciler yuvalarının aslanı içine alacak kadar büyük olup olmadığını anlatan birer mektup yazar ve sesli bir şekilde arkadaşlarına okurlar. Çalışma tüm hayvan rolündeki öğrencilerin mektuplarını yazıp okumasiyla son bulur.

3. Sonuç etkinlikleri (Değerlendirme): Öğretmen öğrencilerden daire şeklinde el ele tutuşarak dizilmelerini ister. Herkesin sırayla bir hayvanın ismini ve yuvasını söylemesiyle oyunu başlatan öğretmen, yanlış söyleyen öğrencinin oyundan çıkmasıyla devam eden oyunu tek bir öğrenci kalana kadar değerlendirme amacıyla devam ettirir.

\section{Ek 3: Ders Planı 3}

Yer: Sinıf ya da drama odaları

Öğrenciler: İlkokul 2. Sinıf

Konu: Değişen evler

Tema: Dün, Bugün, Yarın

Süre: $40 \mathrm{dk}$.

Yöntem ve teknikler: Canlandırma, telefon görüşmesi, tartı̧̧ma,

Araçlar ve gereçler: Birim küpler

Kazanımlar:

1. Geçmişten günümüze binalarda ne gibi değişiklikler olduğunu araştırır ve açıklar.

Ö̆̆renme öğretme süreci: Öğretmen sınıfa "Çocuklar duydunuz mu, okulun yanına gökdelen yapılacakmış, doğru mu?" diyerek heyecanlı bir şekilde sınıfa girer.

1. Giriş etkinlikleri (Hazırlık): Öğrencilerin kendi aralarında gruplar oluşturmasını isteyen öğretmen ellerindeki birim küplerle kendilerince gökdelen yapmalarını ister. Çalışma kısa bir süre devam eder.

2. Geliştirme etkinlikleri (Canlandırma): Sınıftan iki öğrenciyi seçen öğretmen birinin tarihi bir bina diğerinin ise yeni bir binaymış gibi hissetmelerini söyler. Sınıfta kendilerini bu binaylarmış gibi anlatmalarını ister. Tam anlatmaları biterken öğretmene bir telefon gelir ve tarihi binanın yıkılacağı söylenir. Tüm sınıfça bu durum tartış1ır.

3. Sonuç etkinlikleri (Değerlendirme): Öğretmen öğrencilere "Geçmişte müteahhitlik yapan yaşlı biri olsaydınız şimdiki binalarda ne gibi değişiklikler yapılmış olduğunu söylerdiniz?” sorusunu sorarak sınıfta tartışma ortamı yaratır.

\section{Ek 4: Ders Plant-4}

Yer: Sinıf ya da drama odaları

Öğrenciler: İlkokul 2. Sınıf

Konu: Yiyeceklerim ve Oyuncaklarım da değişiyor.

Tema: Dün, Bugün, Yarın

Süre: $40 \mathrm{dk}$.

Yöntem ve teknikler: Şapka kimdeyse oyunu, bölünmüş ekran, rol oynama, soru cevap

Araçlar ve gereçler: Şapka, müzik 


\section{Kazanım:}

1. Bebeklik ve çocukluk döneminde tükettiği yiyecek- içecekleri, oyun ve oyuncakları karşılaştırarak, bu tür değişikliklerin doğal bir olgu olduğunu kavrar.

Öğrenme öğretme süreci: Öğretmen bebekken insanların neden bunları 1sırarak yiyemediklerine ilișkin düşüncelerini sanki kendi kedinine konuşuyormuş gibi sesli bir şekilde ifade ederek öğrencilerin dikkatini çekmeye çalışır.

1. Giriş etkinlikleri (Hazırlık): Öğretmen sınıfa bir bebek şapkası getirir. Bebeklerin nasıl hareket ettiklerini göstermek için gönüllü öğrencilerden birinin bu şapkayı takmasını ister. Müzik eşliğinde şapkayı sırayla takan her öğrenci bebekmiş gibi hareket eder. Çalışma tüm sınıfın katılımıyla sona erer.

2. Geliştirme etkinlikleri (Canlandırma): Öğretmen sınıftan gönüllü altı öğrenciyi seçerek ikisine "baba", diğer ikisine "anne" ve son kalan öğrencilere de "bebek" ve "çocuk" rollerini dağıtır. Seçilen öğrencilerden anne, baba ve çocuktan oluşan aileyi temsil edecek şekilde iki grup oluşturmalarını ister. Gruplardan biri Ayşe'nin annesini, babasını ve Ayşe'nin bebeklik halini, diğer grup da annesinin, babasının ve Ayşe'nin ilkokula giderken olan hallerini canlandırır. Ayşe'nin nasıl yemek yediğini, hangi oyuncaklarla oynadığını gösteren sahnelerde ilk grup canlandırma yaparken ikinci grup hareketsiz bir şekilde bekler.. Öğretmenin parmağını şıklatmasıyla ilk grup donar, ikinci grup aynı sahneyi 6 yıl sonraki halleriyle çağa uygun olarak canlandırır. Çalışma bir süre diğer öğrencilerin gözlemlemesiyle de devam eder.

3. Sonuç etkinlikleri (Değerlendirme): Öğretmen “Oyunda neler yaşadınız ve hissetiniz?”, “Tekrar bebek olmak ister misiniz?" gibi sorular yönlendirir.

\section{Ek 5: Ders Planı 5}

Yer: Sinıf ya da drama odaları

Öğrenciler: İlkokul 2. Sinıf

Konu: Canlılar büyür ve gelişir

Tema: Dün, Bugün, Yarın

Süre: $40 \mathrm{dk}$.

Yöntem ve teknikler: Göz kırpma oyunu, rol oynama, geriye Dönüş

Araçlar ve gereçler: Bebek şapkası

\section{Kazanım:}

1. Canlıların hayatta kalabilmeleri için nelere ihtiyaçları olduğunu araştırır.

Öğrenme öğretme süreci: Öğretmen sınıfa girdiğinde kendi evinde bulunan çok sevdiği bir çiçeğinin, ona hergün iyi baktığı halde solduğunu anlatarak derse başlar.

1. Giriş etkinlikleri (Hazırlık):Sınıftaki her bir öğrencinin kendisi için nadide bir çiçek olduğunu belirten öğretmen, göz kırpma oyunu ile onlara sevgisini göz kırparak göstereceğini söyler. Sınıfta dolaşmaya başlayan öğretmen kime göz kırparsa o yavaşça ayağa kalkar ve öğretmenin arkasından dolaşmaya başlar. Göz kırpılmadan kim ayağa kalkarsa oyun çıkar.

2. Geliştirme etkinlikleri (Canlandırma): Öğretmen sınıftan bir grup öğrenciyi seçerek “anne”, "baba” ve "çocuk ve bebek" rolünü oynamak üzere öğrencilere dağıtır. Doğaçlamanın başlamasıyla anne ve baba bebeğin büyümesi için ona su, yemek verir, dışarıda hava alması için gezdirir, oyunlar oynatır ve tuvalete götürür. Öğretmenin elini şıklatmasıyla bebek beş yaş büyür. Anne, baba ve geleceğe giderek canlandırmaya devam ederler. Öğretmen tekrar parmağını şıklatır ve çocuk beş yaş küçülür ve çocuk küçüldüğü belirtmek için başına bebek şapkası takar. Anne, baba ve çocuk tekrar geçmişe dönerek doğaçlama yaparlar. Öğretmenin parmağını şıklatmasıyla kontrolü sağldığı çalışma öğrencilerin geçmişi ve geleceği aynı anda gözlemlemeleriyle birlikte çalışma öğrencilerin yaratıcılıklarına bağlı olarak devam eder.

3. Sonuç etkinlikleri (Değerlendirme): Öğretmen sınıftaki öğrencilerden su grubu, hava grubu, yiyecek grubu olmak üzere üç grup oluşturmalarını ister. Öğretmen "Sizce bir canlı içinizden en çok hanginize ihtiyaç duyar” sorusuyla tartışma ortamı yaratır. Her grup kendini haklı çıkarmaya çalışır. Çalışma 5 dakika sürdükten sonra öğretmen öğrencilerin kağıda canlıların neye ihtiyaç duyduğunu birer cümle ile yazmalarını ister. Sonra kağıtları buruşturup birbirine atan öğrenciler kağıdı okuduktan sonra tekrar buruşturup başka arkadaşına atar. Etkinlik bir süre böyle devem eder. 
